\title{
DIE OORGEBLEWE SENDINGTAAK IN SUID-AFRIKA
}

\author{
J J KRITZINGER
}

\begin{abstract}
The remaining missionary task in South Africa

This article is based on the results of a research project of the Institute for Missiological Research at the University of Pretoria which was recently concluded. The author and a team of co-workers researched practically the whole of South Africa in an endeavour to describe the contemporary situation of its population and the unfinished task of the church. The understanding of the missionary task which formed the basis of this project, and a sample of the kind of results obtained are illustrated in this article by means of 12 representative or typical scenarios which together indicate the dimensions of the future task for the South African church.
\end{abstract}

Sedert 1981 was skrywer hiervan persoonlik en in samewerking met ' $n$ hele aantal medewerkers besig met ' $n$ ondersoek wat genoem is Die Onvoltooide Sendingtaak in Suid-Afrika. Miskien sou die lesers van Skrif en Kerk geïnteresseerd wees in 'n kort oorsig van die bevindinge.

Dit is belangrik om te besef hoe moeilik dit is om binne die bestek van enkele bladsye ' $n$ ondersoek wat meer as ses jaar geduur het en uitgeloop het op nie minder nie as 36 navorsingsverslae saam te vat in enkele hooftrekke. Dat dit tog gedoen word, is omdat dit uitermate belangrike studies is wat ook op hierdie manier onder die aandag moet kom.

Eerstens sal aangetoon word dat hierdie navorsing 'n nadenke oor die inhoud van sending gestimuleer het.

Hierdie navorsingsprojek het ook op 'n besondere manier kerklike kringe se aandag gevestig op die verskeidenheid van kontekste waarbinne die kerk sy sendingroeping moet uitleef. In die tweede plek word iets hiervan deurgegee. Telkens word dan ' $n$ aanduiding gegee van die uitdagings wat hierdie scenario's in terme van die oorgeblewe sendingtaak tot die kerk rig.

\section{Sendingbegrip}

Dit het baie spoedig geblyk dat daar nie maar net aanvaar kon word dat 
almal weet wat onder "sending" verstaan word nie. Anders gestel, feitlik elke mens en kerklike groepering het 'n eie siening van wat nou eintlik sending is.

Die titel van die navorsingsprojek is egter aangekondig as "die onvoltooide sendingtaak". Dit was daarom onvermydelik dat daar aanvanklik misverstande sou opduik. Inderdaad het die projek veroorsaak dat ' $n$ baie belangrike gesprek in die NG Kerkkringe aan die gang gekom het. Veral die NG Sendingkerk het die saak ernstig opgeneem en het hiervoor ' $n$ werkswinkel gereël. Sterk afvaardigings van die NG Kerke het vir 'n paar dae met mekaar gekonfereer op weg na 'n nuwe werkdefinisie van sending. 'n Hoogs betekenisvolle dokument het daaruit die lig gesien, gepubliseer deur prof Phil Robinson en ds Johan Botha as Wat is sending? (Bellville, 1986).

Vanuit die staanspoor sou ons ons in ons definisie moes afgrens van enkele (volgens ons) foutiewe sieninge.

* In die eerste plek is daar die siening van die man in die straat wat sending beperk tot kerkwerk onder swartes (oftewel nie-blankes). Enige kerk- of evangelisasiewerk wat gerig is buite die blanke gemeenskap word dan as sendingwerk beskou. ' $n$ Sendeling is per definisie iemand wat (net) onder nie-blankes werk. Een van die probleme hiermee is dat die sending nou op 'n onregverdige wyse in die rasse-politiek van die dag ingesleep word. Heelwat antipatie teen die sending word so opgewek, gevoed deur allerlei uitgediende opvattinge oor die sending.

In hierdie projek is ons dus gedwing om in 'n mate te polemiseer teen die gangbare onderskeiding wat daar in (onder andere) die NG Kerk tussen "sending" en "evangelisasie" gemaak word. Sonder dat dit kerkordelik so beskryf word, kom dit in die praktyk ongelukkig meestal daarop neer dat die kleur van die betrokkenes bepaal watter kommissie die aangeleentheid sou hanteer. Uit die perspektief van hierdie navorsingsprojek kon dit nie alleen glad nie aanvaar word nie, maar die tragiese gevolge van hierdie misverstand is om elke draai raakgeloop. Die sending moes ten alle koste van sy kleurkonnotasie bevry word.

Om enigsins hierdie verkeerde siening teen te werk, het die navorsers in hierdie projek baie doelbewus na alle gemeenskappe in die betrokke gebied gekyk. Dit moes baie duidelik in die behandeling uitkom dat die onvoltooide sendingtaak ook met die tradisioneel christelike blanke gemeenskappe te doen het. Trouens, daar moes klem gelê word op die feit dat ' $n$ groeiende groep blankes hulleself as ongelowiges begin identifiseer, net soos wat 'n oorgrote deel van die nie-blanke gemeenskappe hulleself lank reeds in die christelike kamp bevind.

* In die tweede plek bestaan daar 'n misverstand by lidmate waarvolgens die sending 'n opsionele aktiwiteit van die kerk sou wees. Daar- 
volgens sou ' $n$ lidmaat die keuse hê om daarby betrokke te wees of nie. Die sending - wat hulle sou toegee ' $n$ goeie ding is - is ' $n$ privaat onderneming van 'n groep "sendingvriende".

Vanuit die staanspoor moes ook hierteen gepolemiseer word. Sending is God se saak. God is die outeur van sending: die Vader is die Beplanner daarvan, en die Sender van die Seun; Jesus is die prototipe van sendelinge, $\mathrm{Hy}$ is gestuur om die Goeie Nuus te word; en die Heilige Gees word deur Vader en Seun gestuur om God se sending voort te sit ... tot vandag toe. Volgens hierdie uitgangspunt, wat bekend staan as die missio Dei, is die kerk as die "liggaam van Christus" met die Gees van Christus vervul, en is die kerk dus in sy ganse bestaan by God se sending betrokke. Dit is geen opsionele saak nie, want deelname aan God se sending is die lewe van die kerk en gee sin aan sy bestaan. Die enigste vraag wat daar vir ' $n$ lidmaat oorbly, is of hy/sy positief meewerk met God, of dalk 'n struikelblok is?

Uiteraard is die sending dus 'n ekumeniese saak. In die onvoltooide sendingtaak (van die kerk) kan nie seksioneel gedink word nie, maar is die ganse "liggaam" in die oog. Dit is ook 'n omvattende saak, want die kerk se hele lewe is daarby betrokke.

* Die derde stel afgrensinge was teen dié sieninge wat sending volledig laat opgaan het in die prediking. Sending moet nie méér probeer doen nie, so word gemeen, as om die "suiwer" evangelie te verkondig en "siele" tot bekering te bring.

Hierteenoor is in hierdie navorsingsprojek uitgegaan van 'n veel meer omvattende verstaan van sending. Op voetspoor van aanvaarde sendingwetenskap word die direkte evangelieverkondiging gesien as net maar een van die dimensies van sending, wel' $n$ baie kardinale en grondliggende dimensie. Sending is egter meer as net evangelisering.

Uiteindelik het ons besluit om te praat van 'n driedimensionele sendingtaak. Dit is so ongeveer gekoppel aan drie geykte Griekse teologiese terme: kerugma staan vir die verkondigende, evangeliserende dimensie; diakonia is die liefdesdiens waardeur die ontferming van God deurgedra word na die lydende mensdom; en die koinonia, gemeenskap, dui op die gemeenskapstigtende en kerkopbouende dimensie van sending.

Sending het dus eerstens daarmee te doen dat mense die evangelie moet hoor, en wel só duidelik moet hoor dat hulle daarop kan reageer. 'n Aanduiding van hierdie dimensie is die mate waarin die mense (statisties) ingeskakel is by die een of ander christelike kerk. 
Daarom is in die navorsingsverslae steeds baie moeite gedoen om die breë statistiese prentjie van die godsdienstige samestelling te teken. Maar dit gee maar net ' $n$ aanduiding, want ten diepste is die hoor en aanvaarding van die evangelie ' $n$ kwalitatiewe saak. Daarom moes die bediening van die evangelie aan en met die oog op die buitestaanders ook geweeg en getoets word.

Met die oog op die tweede dimensie is baie moeite gedoen om gegewens omtrent die lewensomstandighede van gemeenskappe byeen te bring. Die behoeftes van mense is so wyd soos die lewe self en word deur ekonomiese, maatskaplike en politieke omstandighede bepaal. Verstedeliking, onderontwikkeling, industrialisasie, werkloosheid, armoede, behuisingsnood, maatskaplike verval, politieke regte, skoolvoorsiening, mediese diens, en nog baie meer, is die groot sake wat aandag moet geniet. Al hierdie dinge moet uitgespel word ter wille van begrip, maar ook met die oog daarop om iets aan die saak te doen. En in dit alles soek die kerk om getrou te wees aan die diepste gesindheid van sy Here, wat nie gekom het om gedien te word nie, maar om te dien.

As die vorige dimensies van die sendingtaak - die goeie woord en die liefdevolle daad - met integriteit uitgevoer wil word, kan die derde dimensie (die koinonia) vergelyk word met die pen wat die twee lemme van 'n skêr aan mekaar heg sodat die skêr kan funksioneer. Alleen die gemeenskap met God en met mekaar maak die sending moontlik. As daar by hierdie dimensie fout is, kan die sending kwalik tot sy reg kom. Die gemeenskap van verlostes is in die sending die draer van Gods bedoeling in die wêreld. Daarom is nie net die totstandkoming van die kerk, deur 'n proses van evangelisering, belangrik nie, maar ook die opbou van die kerk het alles met die sending te make. Juis hierdie gemeenskapstigtende en gemeenskapopbouende werk maak dus die uitvoering van die ander dimensies enigsins moontlik.

Hierdie spesifieke formulerings is nie bedoel om die finale woord oor ' $n$ sendingdefinisie te wees nie, maar dui alleen die breë benadering aan. Trouens, hierdie driedimensionele benadering is meer as net implisiet ook in die NG Kerk se amptelike Sendingreglement teenwoordig.

Die werklike probleem ontwikkel egter wanneer die implikasies van hierdie benadering uitgespel moet word. Dit is op hierdie punt dat ernstige verskille tussen kerke en individue na vore kom. Dit is alles goed en wel as gesê word dat die kerk in sy sending 'n diakonale taak het, en dat hierdie diakonaat verder moet gaan as die blote verbinding van die wonde, en ook die strukturele kwaad moet bestry. Maar wanneer hierdie strukture geïdentifiseer en teengewerk moet word, dan skei die weë.

In die navorsing moes rekening gehou word met al hierdie dimensies. Alle relevante gegewens moes byeengebring word sodat die taak sy 
volle omlyning kon vind.

\section{Scenario's}

Een van die belangrikste implikasies van die behoeftegerigte sendingbenadering is die besef dat elke situasie uniek is en sy eie sendingstrategieë verg. Daar is in werklikheid nie so iets soos 'n algemene of selfs tipiese situasie waarvoor daar geykte oplossings en metodes bestaan nie. Daarom moet elke situasie op sigself bestudeer en beoordeel word.

'n Verskeidenheid van faktore konstitueer 'n situasie. Kyk ons na die gemeenskappe vanuit die perspektief van die oorgeblewe taak van die kerk, is die twee belangrikste aspekte waarmee al die ander saamhang, (a) die godsdienstige opset, en (b) die algemene posisie op die ontwikkelingskontinuum. By die godsdienstige opset is dit belangrik om te weet in watter mate die gemeenskappe gekersten is, en of daar oorheersende kerklike groeperinge is. Aan die ander kant bepaal die mate van verstedeliking, die ligging van die gebied, en die algemene sosio-ekonomiese posisie van die bevolking die ander dimensies van die situasie.

Ten spyte van wat hierbo gesê is oor die uniekheid van elke situasie, sal tog 'n poging aangewend word om die ryke verskeidenheid van situasies in Suid-Afrika ter wille van ' $n$ oorsig saam te vat in ' $n$ aantal "tipiese" scenario's. Telkens sal dan 'n aanduiding gegee word ven die sendingprioriteite in 'n situasie soos daardie.

Hier volg dan sowat 'n dosyn scenario's:

\section{'n Tradisionele gemeenskap, onderontwikkeld, met klein kerklike aanhang}

1. Dit is die situasie wat die klassieke "sendingveld" van die man in die straat is: die "heidenland". Hier het die sogenaamde "comprehensive approach" tot gevolg gehad dat "sendingstasies" opgebou is met hospitale, skole, werkswinkels, ensovoorts; waar 'n groot sendingpersoneel saamgetrek is wat op die verskillende terreine diens gelewer het; en waaruit "sendingkerke" gebore is. Dit was die soort sending wat in die vyftigerjare in die Transvaalse laeveld, die Transkei, en elders ' $n$ dramatiese oplewing getoon het. Die publisiteit daaraan verbonde, saam met die klassieke sendingliteratuur, het veroorsaak dat dit steeds die beeld is wat die deursnee persoon van sendingwerk het.

2. Die situasie wat ons hiser skets, kan vandag nog herken word in 
gebiede soos Venda, en groot dele van Gazankulu, Lebowa, KwaZulu en Transkei.

Kenmerkend hiervan is die relatief lae kerklike aanhang met gevolglik mindere christelike invloed op 'n sterk tradisionele gemeenskap. Die volgende tabelletjie met 1980-gegewens dui aan wat bedoel word.

Nasionale staat Distrik

Venda

Gazankulu

Lebowa

KwaZulu
Malamulele

Giyani

Bochum

Bolobedu

Msinga

Ingwavuma
Kerklik ingeskakel

Die tradisionele aard van die gemeenskappe kan reeds oppervlakkig afgelees word van die argitektuur en die gewoontes om die huis, maar ook in kleredrag en in bepaalde gebruike soos feeste en inisiasie. Hierdie is sigbare tekens van 'n sterk houvas wat die tradisionele gesag (kapteins en dokters) en die tradisionele lewens- en wêreldbeskouing op die algemene bevolking het.

3. 'n Verdere oorweldigende indruk van hierdie gebiede is die neerdrukkende sosio-ekonomiese situasie. Die ontoereikende infrastruktuur is ' $n$ aanduiding van die afwesigheid van enige ontwikkelings- en produksie-inisiatiewe. Die bevolkingsdruk en die (gevolglike) afwesigheid van (veral) mans het ' $n$ afvalproses in die gemeenskap begin wat alreeds sigbaar is in uiterlike dinge soos die slordigheid en verval van huise, onproduktiewe landerye, toenemende ontbossing en die gepaardgaande gronderosie. Werklike armoede en geestelike veragterliking - ' $n$ armoedekultuur - het ingetree.

Onhigiëniese toestande stel gaandeweg groter eise aan 'n gesondheidsdiens wat toenemend gebuk gaan onder personeel- en finansiële tekorte, sodat die gevaar van verwoestende epidemies 'n werklikheid word. Dit alles ondermyn die moontlikheid van verhoogde onderwysstandaarde, want 'n onbeteuelde bevolkingsaanwas gepaard met verslegtende sosio-ekonomiese toestande, oefen invloed uit op die algemene mensemateriaal en die voorsiening van dienste.

'n Klompie feite kan hierdie algemene beskrywing illustreer:

* Van die nuwe werksoekers van Venda het 53 persent in die sewentigerjare geen werkgeleentheid kon bekom nie, en ' $n$ verdere 21 persent slegs buite die gebied. 
Hulle word dus gevoeg by die ongeveer 77 persent van die bevolking wat as surplus op die landbougrond beskou kan word.

- In Lebowa as geheel is die manlike afwesigheidskoëffisiënt teen die ouderdom van 30 so hoog as 66 persent. In sekere distrikte is dit selfs hoër.

* Die gemiddelde inkomste per huishouding in Sekhukhuneland was in 1970 so laag as R42,50 per persoon per jaar.

* In Gazankulu is daar meer as vyf vrouens vir elke aanwesige man in die ouderdomsgroep $25-29$ jaar. 77 persent van die manlike bevolking is jonger as 20 jaar. Slegs een uit elke drie werkers kan binne die gebied werk vind, terwyl vyf ander werkloos moet bly.

5. In hierdie donker-geskilderde situasie is die kerklike situasie grootliks verinheems. Slegs enkele van die groter kerke het nog 'n noemenswaardige aantal blanke personeellede, en dan feitlik slegs geordendes. Die tradisionele dienste van hospitaal en skool het reeds oorgegaan na die staat, en word feitlik uitsluitlik deur swartes (plaaslik, maar hoofsaaklik ingevoer) beman. Die gevestigde kerke met hulle swaar bedieningstrukture sukkel om kop bo water te hou. Die dinamiese groei en ondernemingsgees - indien wel teenwoordig - word gevind by ò nuwere Pinkstergroepe of die onafhanklike inheemse bewegings.

5. Dit is duidelik dat vir die voortgang van die Koninkryk in situasies soos hierdie, nuwe benaderings geverg word. Mannekrag - en finansiële vermoëns - sal op 'n nuwe manier aangewend moet word. Die hoofsake wat die aandag van die plaaslike en die sendende kerke sal moet geniet, is (a) die algemene bestaansnood van die mense, (b) die feit van groot getalle mense wat nog nie bereik is nie, en (met die oog dáárop), (c) die stagnasie en strukturele nood van die kerke.

Alhoewel die sleutel by die plaaslike kerk lê, is hulp van buite beslis nog nodig. Dit sal veel wysheid vra om so te help dat die hulp nie 'n verslawende effek het nie, maar bevry tot die aanvaarding van eie verantwoordelikheid.

Meer moderne, maar onderontwikkelde gebiede, met taamlike groot kerklike aanhang

1. In dele van Lebowa, KwaZulu, Transkei en KaNgwane, maar veral Bophuthatswana, Qwaqwa en Ciskei is die bevolking prakties geheel en al by christelike kerke ingeskakel. Kyk na die volgende:

Gebied

Moutse (Lebowa)
\% kerklik ingeskakel

$82 \%$ 
Vulindlela (KwaZulu)

Eerstehoek (KaNgwane)

Bophuthatswana

KwaNdebele

OwaQwa

Ciskei
$85 \%$

$76 \%$

$95 \%$

$85 \%$

$89 \%$

$81 \%$

2. Hier het reeds 'n groot mate van modernisasie ingetree, deels as gevolg van die jarelange kontak met die sending en ander Westerse tipe ontwikkeling. Nogtans mak ook hierdie gebiede deel uit van die buiteperiferie van die Suid-Afrikaanse ekonomiese struktuur. Die bestaansekonomie raak toenemend onmoontlik weens die bevolkingsdruk, en die ligging van die gebiede maak dit veral aangewese op kontantinkomste van trek- en pendelarbeiders.

Die kontant laat sekere sektore van die bevolking ' $n$ verhoogde lewenspeil vertoon, maar die algemene ontwikkeling van die gebiede laat veel te wense oor: paaie is swak, telefone en poskantore skraps, elektrisiteit ' $n$ uitsondering, water 'n eksistensiële probleem, goed ontwikkelde dorpe met die nodige dienste bestaan nie, om nie te praat van nywerhede en werkverskaffing nie.

3. Die kerk het hier 'n erkende rol en die gemeenskappe beskou hulleself as christelik. Meestal kan hier teruggekyk word op meer as 'n eeu se sterk christelike invloed, sodat daar nie gehou word van die gedagte dat hier "sendingwerk" gedoen word nie. Dit plaas 'n groot verantwoordelikheid op die plaaslike kerke. Hulle sal 'n betekenisvolle teenwoordigheid moet hê. Die nodige ontwikkeling sal begelei moet word sodat die "hart" van die ontwikkeling - naamlik die verandering van die mens, sy lewenshouding en mentaliteit - nie daaruit ontbreek nie.

4. Die primêre taak van die kerk in hierdie situasie lê daarin om die probleem van nominaliteit te bestry. Hier het dit reeds gewoonte geword om ' $n$ christen te wees. Kerklike belydenisaflegging het 'n sosiale gebeurtenis geword soos die "boerematriek" van die verlede.

* In Bophuthatswana is dit ' $n$ groot belediging om as ' $n$ nie-christen beskou te word. Almal beskou hulleself as christene, al is ' $n$ minderheid lidmate van ' $n$ kerk. Die sogenaamde "barati" (die ongedefinieerde "aanhangers") is egter net so getalryk as die volle lidmate.

Die kerk sal 'n bedieningstruktuur en -rol moet vind om daadwerklik kwalitatiewe groei te bewerkstellig. Die taak van kwantitatiewe groei (werwing en rekrutering) is hier beslis minder belangrik as die op- 
bou van die kerk. Ook hier lyk dit egter asof nuwe bedieningstrukture gevind sal moet word. Die ou manier van doen, slaag nie. Dit word bevestig wanneer gelet word op die groeiende invloed van klein, entoesiastiese, mobiele verenigings en kerklike bewegings wat op kwalitatiewe beslissings en ondervinding van spiritualiteit aandring.

\section{Nuwe saamtrekke en hervestigingsgebiede met plakker- bevolkings}

1. In al die nasionale state is daar hervestigingsgebiede waar tienduisende (en in sommige gevalle honderdduisende) mense hulle asof uit die niet kom vestig het om 'n nuwe begin te maak. Daar is verskeie kategorieë van hervestigingsgebiede. Sommige het "spontaan" ontstaan. In daardie gevalle was daar geen dwang anders as die druk van omstandighede wat die mense beweeg het om te trek nie. Slegs in enkele gevalle is die stap uit vrye keuse en met entoesiasme geneem. Maar die meeste gevalle was die gevolg van 'n beleid van hervestiging waarvolgens individue en gemeenskappe met 'n mate van dwang verskuif is na terreine wat ideologies gesproke as meer geskik beskou is. Dit was veral plattelandse "swart kolle", maar ook stedelike en plaasmense wat verskuif is na saamtrekplekke binne die nasionale state.

2. Die belangrikste voorbeelde in hierdie kategorie is die saamtrekke digby die stede, soos Botshabelo naby Bloemfontein (wat eintlik ' $n$ ietwat ander saak is), KwaNdebele en die Winterveld en ander gebiede naby Pretoria, en groot gebiede om Durban, Oos-Londen en Kaapstad. Maar die talle gevalle elders in KwaZulu, Ciskei, Bophuthatswana en KaNgwane moet nie vergeet word nie. Daar word beweer dat meer as drie miljoen mense so verskuif is, maar ' $n$ paar miljoen meer het nadergeskuif en woon in spontane nedersettings ("plakkerkampe") aan die buitewyke van die stede.

3. Kenmerkend van al hierdie saamtrekke is die feit dat hulle nuut is, en groot in omvang, woondorpe waar ' $n$ dekade of wat gelede net bos of weiveld was. Hulle lyk almal op die oog af soos ongeordende plakkerbuurtes (slums) weens die materiale van sink, modder, tak en seil waarmee die skuilings opgerig is. Eers by nadere ondersoek blyk dit dat die meeste gemeenskappe geordende (selfs opgemete) patrone vorm. Sommige het egter inderdaad spontaan, sonder enige vorm van beplanning tot stand gekom.

4. Die eerste en voor-die-hand-liggende werklikheid by so 'n situasie 
is dus die saak van huisvesting. Almal, letterlik almal, is in die een of ander stadium van huisbou. Almal het te doen met die praktiese probleme van die beskikbaarheid en koste van materiale, die gebrek aan tyd en bouvernuf, en die ordening van alles tot 'n higiëniese en huislike geheel. Dit is ontwortelde gemeenskappe wat fisies besig is om weer wortel te skiet.

5. Maar dit is ook geestelik ontwortelde gemeenskappe. 'n Nuwe gemeenskap moet tot stand kom uit individue wat al hulle vorige familiebande, buurskappe en werkgemeenskappe, ja ook hulle bekende plekke, moes agterlaat. Gemeenskapstigting en gemeenskapsontwikkeling is hier die kernbegrippe. Die gemoedstoestand van die mense hang grootliks af van die manier waarop hulle hier aangekom het. Veral hulle wat hierheen verskuif is, is geensins geneë om met positiewe programme saam te werk nie. Dit kan nie genoeg beklemtoon word hoe belangrik die werk van die kerk, veral op die gebied van diakonia en koinonia, in situasies soos hierdie is nie.

6. Nou is dit so dat hierdie saamtrekke van die hoogste nominele ingeskakeldheid by kerke vertoon. Maar ongelukkig het die meer gevestigde kerke meestal nie daarin geslaag om saam met die mense te trek nie. Die meeste lidmate word maar aan hulleself oorgelaat, sonder dat hulle daarop voorberei is. Die gevestigde kerke se strukture maak gewoonlik nie voorsiening vir so ' $n$ vinnige hergroepering van mense nie. 'n Absolute prioriteit in die bediening sou wees om die verspreide lidmate met mekaar in verbinding te bring sodat daar weer ' $n$ gemeentelike lewe en bediening opgebou kan word.

Intussen het die meer spontaan georganiseerde, maar dikwels vlakker en meer sinkretistiese bewegings die lugleegte gevul. Hulle bied van huis uit 'n groter ruimte vir leierskapsinisiatief met die gevolg dat hierdie kerke die behoeftes vinniger kan aenvoel en daarop kan reageer. Groepe word gevorm wat eintlik die nuwe tuiste, die nuwe familiekring vir ontwortelde mense word.

Struktureel bied hierdie bewegings die antwoord. Terwyl die ouer kerke nog vergaderings hou om die situasie te ondersoek, het hierdie nuwe bewegings lankal reeds begin funksioneer. Maar hoedanig is die Bybelse onderrig wat gebied word?

\section{Ekstensiewe boerderygebiede}

1. Die grootste deel van die land, en bykans 20 persent van die bevolking, het te doen met die ekstensiewe vee- en saaiboerdery van die 
kommersiële landbousektor. Hier dink ons veral aan die uitgestrekte Karoo, Noord-Kaaplandse, Vrystaatse en Bosveldse veegebiede en die uitgestrekte saaigebiede van die Mieliedriehoek en ander hoëveldgebiede. Die plaasbevolking van hierdie streke wissel van 'n oorwegend kleurling- in die suidwestelike dele tot ' $n$ uit en uit swart bevolking in die noorde en ooste. Die blanke besittersklas is deurgaans ' $n$ klein minderheid op die plase en deur hulle relatiewe welvaart minder onderhewig aan die tipiese probleme wat hier aangedui gaan word. Alhoewel die aard van die landbou saam met die klimaats- en ander omstandighede wissel, is daar ' $n$ paar faktore wat hierdie boerderystreke gemeen het.

2. Die uitgestrektheid van die gebied en verspreidheid van die bevolking is kenmerkend. Die plase is groot, en die bedryf nie so arbeidsintensief nie. Daar is dus op elke plaas, ver van mekaar, enkele gesinne woonagtig. Nie alleen kan hierdie klein groepies mense nouliks lewensvatbare gemeenskappe op sigself wees nie, maar die uitgestrektheid en dun bevolking maak die verskaffing van dienste baie moeilik en relatief duur. Dit geld vir skool, gesondheid, kommunikasie, maar ook kerkwerk.

3. Kenmerkend van die plaasbevolking, sy hulle bruin of swart, is die armoede. Hieroor is genoeg gegewens beskikbaar. Maar armoede het nie alleen 'n basiese finansiële komponente (lae inkomste) nie, maar 'n sosio-psigologiese dimensie: dikwels is die plaasbevolking vasgevang in 'n armoedekultuur. ' $n$ Situasie heers waaruit daar moeilik ontsnap kan word. Trouens, hierdie soort chroniese toestand ontneem mense die wil om iets aan hulle eie situasie te doen, selfs al word die moontlikhede geskep.

4. Die wortels daarvan lê in die geskiedenis waardeur die heersende paternalistiese samelewingstruktuur op die platteland gevestig is. Die mense is in alle opsigte aan die plaaseienaar-boer uitgelewer. Hulle teenwoordigheid en voortgesette verblyf op die plaas is afhanklik van die goedkeuring van die boer, die huisvesting, die skool (indien teenwoordig), behoort aan die boer, die aard en omvang van vergoeding en ander voordele word eensydig deur hom bepaal, terwyl enige ander dienste ook van hom afhang. Die plaaswerkers het geen sê nie en moet vir alles maar opkyk na die "baas". Op so 'n manier word inisiatief gedemp.

5. Tog is die kerk meestal nomineel reeds op die plase gevestig. Dit is dus die bediening van hierdie verspreide lidmate wat die eerste besondere uitdaging aan die betrokke kerke bied. Trouens, dit is 
oorvloedig duidelik dat die kerke met huidige mannekrag, finansiële voorsiening en geykte bedieningstrukture nie daarin slaag om hierdie mense na behore te bereik en op te bou in die geloof nie.

6. Die roeping van die kerk in hierdie plaasdistrikte gaan egter veel verder as die blote kerklike bediening van die verspreide lidmate. Die kerk het hier met mense te doen wat weens verskillende omstandighede agtergebly het. Hier word besondere sorg gevra op die terrein van die diakonaat. Maar die diakonaat gaan op sy beurt verder as die blote sorg vir slagoffers van omstandighede. Dit behels ook ' $n$ profetiese intrede ten bate van die swakkes en armes sodat hulle ' $n$ beter kans in die lewe gegun kan word. In wese is die taak van die kerk hier een van gemeenskapsontwikkeling, in samewerking met die mooi inisiatiewe wat reeds bestaan.

7. Een spesifieke taak wat in samehang met wat hierbo gesê is, beklemtoon kan word, is die saak van plaasskole. Veral die swart plaasbevolking is daar baie swak aan toe. Die kerk se strukturele en plaaslike bemoeienis hiermee kan gemotiveer word uit al die dimensies van die kerk se roeping: die verkondigings- en bedieningsbehoeftes vra daarvoor; geregtigheidsoorwegings maak dit dringend; en vir die doel van gemeenskapsontwikkeling is dit ' $n$ kernelement in enige program.

\section{Intensiewe boerderygebiede}

1. In teenstelling met die ekstensiewe boerderye word hierdie scenario gekenmerk deur kleiner plase met arbeidsintensiewe boerderyvertakkinge wat hoofsaaklik besproeiing behels. Daar is talle groot besproeiingskemas langs die riviere van ons land. Die grootstes hiervan is seker Vaalharts en die Benede-Oranje, maar onderkant verskeie ander groot damme soos Loskop en Hartebeespoort is daar gebiede waar op 'n intensiewe wyse vrugte en groente verbou word. Die hele Boland kan eintlik ook daaronder geklassifiseer word.

2. Terwyl die plaaswerkers by hierdie plase in ongeveer dieselfde wetlike en sosio-ekonomiese posisie as hulle eweknieë op die groter plase verkeer, is hulle in sommige opsigte selfs nog slegter daaraan toe weens die verhoogde produksiedruk eie aan hierdie sektore. Hierdie boerderye is vir alle praktiese doeleindes fabrieke, maar sonder dat die arbeidswette van die sekondêre nywerhede hier geldig is.

3. Hierdie plaasbevolking woon hoofsaaklik in groter saamtrekke. 
By verskillende van hierdie skemas woon die arbeiders inderdaad in "dorpies" waarvandaan hulle daagliks werk toe pendel. Hierdie ontwikkeling is aan te beveel omdat dit allerlei normale gemeenskapsaktiwiteite moontlik maak, asook sake soos huiseienaarskap, en so meer.

4. Ook hier sal die kerk se taak grootliks gerig moet word op aksies wat hierdie gemeenskappe bevry tot groter deelname aan hulle eie toekoms. Die oorbekende sosiale wantoestande en die neersuigende draaikolk van gemeenskapsarmoede moet deurbreek word met 'n gekoördineerde program van gemeenskapsontwikkeling. Die kerk sal hier ' $n$ unieke bydrae moet lewer, in samewerking met die ander instansies wat reeds op hierdie terrein aktief is.

5. Die bediening van die gemeentes gaan hier nie met soveel logistiese probleme gepaard as op die uitgestrekte platteland nie. Nogtans sal hierdie gemeentes hul eie besondere probleme hê om te oorkom. Hier, soos ook elders, sal die klem moet val op gemeentebou deur middel van die skoling van veral die ampsdraers/leiers by die verskillende saamtrekke.

\section{Trekarbeiders in die stad, op die myne en op die platteland}

1. Trekarbeid is een van die mees berugte aspekte van die SuidAfrikaanse samelewing. Dit is reeds van alle kante gekritiseer, sonder dat daar egter regtig dramatiese vordering in die uitskakeling daarvan gemaak kon word. Die vroegste aanvange van die industriële tydperk in Suid-Afrika het reeds hiermee gepaard gegaan. Geslagte swartmense het nooit ' $n$ ander werklikheid geken as dat jongmense, om die pot aan die kook te hou, hulle tuiste moes verlaat en vir 'n korter of langer tyd in die stede of op die myne moes gaan werk nie. Waar die stelsel aan die begin dalk prakties gesproke noodsaaklik was om arbeid vir die kortstondige mynbedrywighede op die hoëveld te voorsien, het dit later egter 'n belangrike fondamentsteen van die ideologie geword waarvolgens swartmense as "tydelik" binne "blanke" Suid-Afrika beskou is. Mettertyd het dit sodanig ' $n$ deel van die ekonomiese struktuur van SuiderAfrika geword dat selfs die opheffing van instromingsbeheer en die afskaffing van alle apartheid waarskynlik nie die stelsel sal kan beëindig nie.

2. Twee aspekte in verband met die trekarbeiders moet kortliks aangestip word. Eerstens is daar die trauma wat met die proses gepaard gaan. Trekarbeiders leef, of probeer leef, in twee wêrelde. Die bedryf waar hy hom nou bevind, het heeltemal 'n ander stel waardes as 
waaraan hy/sy gewoond geword het. Hier geld ander reëls, 'n ander lewenswyse. Niks wat tot dusver geleer en beoefen is, is hier van enige waarde nie. Van die nuwe trekarbeider word feitlik ' $n$ wedergeboorte vereis; 'n nuwe mens wat hier kan oorleef, moet gebore word. Nuwe eise word gestel en, dalk vir die eerste keer, word die persoon deur 'n "baas" verskree. Werk is nou aan die lopende band en word gereguleer nie meer deur die son nie, maar ' $n$ sirene. En daar is groot gevare verbonde aan hierdie werk en in die nuwe samelewing.

\footnotetext{
*Die vreemde wêreld van die witman, al word hy ook hoe goed daarop voorberei, gaan direk teen die geloof en begrip van die tradisionele swartman in. Verstaan kan en wil hy nie, maar die voordele daarvan wil hy geniet. Trouens, hy het nie die keuse nie: oorlewing gebied dit. Hy moet maar in die moderne industrie of myn gaan werk. Die enigste 'behoud' gaan wees om ' $n$ 'ander kombers' aan te trek, ' $n$ 'robot' te word. Dan kan al die dinge oor ' $n$ mens spoel soos water oor ' $n$ eend se rug. Dit sal jou nie raak nie en jy sal 'ongeskonde' by die huis terugkom. Daarom die onverbiddelike onbetrokkenheid: dit gaan om oorlewing!
}

3. Die tweede aspek is die behuising. Die trekarbeiders kom as individue na die werk en word as sodanig gehuisves in enkelkwartiere. By die moderne myne veral is hierdie kwartiere (kampongs) smaakvol en die versorging so goed as moontlik. Waar die mense egter in die stede by ' $n$ verskeidenheid van werkgewers in diens is, moet hulle maar in munisipale en ander hostelle verblyf kry. Hier word alleen 'n slaapplek gehuur en die versorging is op eie rekening. In die meeste gevalle is hierdie soort verblyf uiters onaangenaam en ongesond. Te midde van die massas is hierdie mense dodelik eensaam - iets wat ' $n$ tradisionele mens nooit kan wees nie omdat hy altyd deel van 'n gemeenskap is.

Die eensaamheid en verlange dryf die persoon meermale tot ongewenste en selfs onnatuurlike praktyke en verhoudinge. Trekwerkers van verskillende geslagte gaan dikwels semi-permanente verbindinge aan om uit die eensaamheid en die onaanvaarbare woonomstandighede te ontsnap. Baie woon dan so (onwettig) in die agterplase van blanke en swart woonbuurtes.

4. Wat is die invloed op die mense tuis? Pas is die een probleem genoem. Talle getroude mans word so vasgevang in hulle nuwe "gesins"-verantwoordelikhede in die stad dat hy nooit meer geld terugstuur nie, en selfs sy ou gesin afsterf. Ander stuur getrou onderhoudsgeld huis toe, maar bly so permanent by die werk dat hy eintlik vir ' $n$ huweliks- en gesinslewe verlore is. Nog ander keer na 'n aantal jare terug as veranderde mense: miskien liggaamlik geknak deur bedryfsiektes, alkohol of veneriese siektes; of geestelik geknak deur die eensame stryd 
teen die gespletenheid van die bestaan.

So word 'n groot koste tuis betaal. Maar daar is ook die ander direkte kostes verbonde aan manlike afwesigheid in die gesin en breër gemeenskap: 'n gesagskrisis wat onhanteerbaar word, en vroue wat die drag nie meer kan dra nie.

5. Wat sê dit alles van die kerk se roeping? Voorop staan seker die kerk se diakonale roeping ten opsigte van 'n gemeenskap wat vir geslagte lank aan onmenslike spanninge onderwerp is. Die kerk sal nooit kan ophou om te soek na alternatiewe vir die stelsel van trekarbeid nie. Geen politieke en ekonomiese sisteem wat hierdie stelsel as ruggraat het, moet langer op die steun van die kerk kan reken nie. Maar die kerk sal ook op dringende wyse die gevolge van die stelsel in die sendende en ontvangende gemeenskappe moet aanspreek. Die bediening van die kerk sal gerig moet wees op die opbou van gebroke huise en gemeenskappe, die skep van moontlikhede van selfversorging, en so meer. (Hier word scenario's 1 en 2 weer teruggevind.) Maar die stede sal ook voorberei en gehelp moet word om ontvangende gemeenskappe te word van nie net individue nie, maar ook gesinne wat agter die werkgeleenthede aan verhuis.

6. Daarmee is tegelyk die dimensie van koinonia aangedui. Hier is met vergane gemeenskappe te doen. Die kerk (in al sy vorme) is egter orals teenwoordig. In watter mate kan die kerk die gebroke gemeenskappe help herstel deur die koinonia met die Skepper en met die medemens te help moontlik maak?

7. Die aktiwiteite op die terrein van die evangelisering van die trekarbeiders verdien alle steun. Trouens, dit is bekend dat die kampongs en hostelle feitlik onbetrede terreine is. Die reeds genoemde faktore maak hierdie ' $n$ baie moeilike arbeidsveld. Beslis sal die kerk se tradisionele metodes hier getoets word. Maar dit beteken nie dat hier nie tog belangrike deurbrake gemaak kan word nie. Talle persone het hier al die ewige lewe gevind en as getuies teruggekeer huis toe.

In die hostelle en op die myne is talle wat (a) uit gebiede kom waar die evangelie maar swak gevestig is, en (b) nog om verskeie redes nie die uitdaging van die evangelie beantwoord het nie. Hierdie mense, soos ook die naamchristene van allerlei afkoms, moet en kan hier met die evangelie in al sy dimensies in aanraking gebring word.

\section{Pendelaars}

1. Pendelary is ' $n$ algemene en natuurlike verskynsel in die stede 
van die wêreld. Mense beweeg heen en weer tussen hulle woon- en werkplek, soms oor ongemaklike afstande. Die twee kritiese faktore is die koste en die tydsduur van die pendelritte. As hierdie ritte te duur word, en die heen- en terugreis onaanvaarbaar lank neem, is verhuising die enigste oplossing.

2. Ons gee hier veral aandag aan swart pendelary, want nie alleen is die omvang daarvan geweldig groot nie, maar dit is ook nie so ' $n$ natuurlike proses nie. In die geval van die swartes het bewegingsvryheid tot onlangs in so 'n mate ontbreek dat daar nie sprake kon wees daarvan dat 'n persoon nader na sy werk kon verhuis wanneer die bogenoemde perke van aanvaarbaarheid oorskry is nie. Die enigste alternatief was maar dié van trekarbeid.

3. Afgesien van die ongeveer twee miljoen swart werkers wat daagliks met openbare vervoer na die sentrale besigheids- en industriële gebiede van die stede en groter dorpe pendel l'n getal waarby die duisende pendelaars met privaat vervoer uitgesluit is), is dit veral die oordie-grens pendeling vanaf die tuislande na die stedelike werkgeleenthede wat ons aandag verg. Hierdie syfer is aan die orde van een miljoen persone daagliks - feitlik ' $n$ half miljoen vanaf KwaZulu na die Durbankompleks, en 'n kwart miljoen vanaf Bophuthatswana na die PWVgebied.

4. In die jongste jare het hierdie getalle snel gegroei. Dit was die gevolg van pogings om weg te beweeg van trekarbeid, sonder om die ideaal van tuislande vir die swart bevolking prys te gee. Slaapdorpe is naby die grense van die industriële gebiede, maar binne die tuislande, aangelê waarheen die meeste nuwe stedelinge gekanaliseer is. Duisende ander mense het nader getrek en rondom hierdie dorpe saamgetrek om so ver as moontlik binne pendelafstand van die stad te kom.

Alhoewel daar baie gepraat is van regte snelvervoer vanaf hierdie gebiede, het daar weens harde ekonomiese werklikhede min van tereggekom. Selfs na die opheffing van instromingsbeheer neem die pendelgetalle nog toe, weens die afwesigheid van beskikbare huisvesting of grond in die "blanke gebiede".

5. Verskeie studies dui aan dat 'n groot persentasie van hierdie pendelaars onaanvaarbare lang ure op die pad deurbring.

" 55 persent van Pretoriase swart pendelaars is langer as drie ure per dag op die pad die internasionaal aanvaarde grens vir ' $n$ billike pendelrit. 
* 25 persent van die KwaNdebele-pendelaars verlaat hulle huise voor 04 h00 soggens en is langer as 16 ure per dag uithuisig.

$\checkmark$ at tref, is dat die studies aandui dat dit veral die ouer, minder gegoede en minder geleerde mense is wat die langste ritte moet onderneem.

6. Die werklike koste verbonde aan pendeling kan onmoontlik deur die werkers gedra word. Talle van hulle het buitendien vroeër (voor die program van bevolkingsverskuiwings) binne loopafstand van hulle werk gewoon. Die regering is verplig om nagenoeg $\mathrm{R} 1000$ miljoen per jaar aan subsidies hiervoor te betaal. Dit word ' $n$ baie duur onderneming. Waarskynlik die duurste aspek is egter die indirekte verlies aan produktiwiteit.

7. Wat ons betref is die belangrikste aspek van die saak egter die invloed op die huislike lewe van hierdie mense. Natuurlik is pendelary verkieslik bo trekarbeid met sy permanent afwesige gesinslede. Maar net tot op 'n punt. Vir talle pendelaars is die huis net maar' $n$ plek waar hy/sy ('n gedeelte van) die nag deurbring. Daar is nie tyd om met die gesin te verkeer nie, daar is nie kans om aandag aan die noodsaaklikste huislike pligte te gee nie, om nie te praat van buitemuurse bedrywighede soos sport, ontspanning of kerk nie. Voeg daarby dat prakties al hierdie mense nuwe intrekkers is wat besig is om hulle huisvesting op te gradeer, en ons kan sien dat die buitensporige ure wat die werkers pendel baie groot spanning op hulle plaas.

8. Ook vir hierdie groep mense sal die kerk 'n bepaalde bedieningstruktuur moet ontwikkel. Dit maak nie sin om net maar op die tradisionele manier te werk te gaan en hierdie mense slegs by die huis te probeer bereik nie.

Talle van hierdie mense het weens hulle lewensomstandighede vervreem geraak van die kerk. Hulle sal weer bereik moet word en wel op die plekke en op die maniere waar hulle beskikbaar is. Is daar nie 'n manier waarop die lang pendelritte benut kan word vir die evangelisering, maar ook die opbou en skoling van die werkers nie?

Maar die gesin tuis het ook eie behoeftes. Deur die lang dae het die vrou en kinders met 'n verskeidenheid van praktiese en ook persoonlike probleme te kampe. 'n Bediening van hulp sou hier van groot waarde wees. Die evangelie het tog met alle aspekte van die lewe te doen!

\section{Minderhede in die stad en op die platteland}

1. Dit het reeds 'n cliché geword dat Suid-Afrika 'n land van minder- 
hede is. Maar daar is wel minderhede waarop die aandag gevestig moet word.

2. In die eerste plek is daar die godsdienstige minderhede. Die Moslems $(1,1 \%)$ en Hindoes $(1,7 \%)$ is in die land as geheel klein minderhede. Alhoewel hulle op sekere plekke (veral in die Durban-gebied en in die Kaapse Skiereiland) nie so ' $n$ klein minderheid is nie, is dit tog elders die geval. Veral op die platteland is dit opvallend dat enkele gesinne, (veral) Moslems tussen ' $n$ see van christene of tradisionaliste hulleself probeer handhaaf.

3. Hierdie situasie hang saam met die verskynsel van etniese minderhede. In elke streek van die land is daar die dominante etniese en taalgroepe en kan dit maklik gebeur dat ander groepies afgeskeep word. Behalwe die Indiërs en Kleurlinge buite hulle tradisionele gebiede, is daar die Vendas, Tsongas, Ndebeles en Swazi's wat feitlik orals buite die betrokke tuislande in klein minderhede voorkom. Maar dan is dit ook die immigrante-groepe soos die Portugese, Grieke, Duitsers, verskeie OosEuropese groepe en ook ander Asiërs wat ter sake is.

4. Drie aspekte in verband met al hierdie groepe moet die kerk se aandag geniet. Eerstens is daar die geregtigheidsaspek. So maklik kan hierdie groepe ondergeploeg word deur die meerderheid. Die kerk sal 'n gevoeligheid daarvoor moet openbaar, sulke sake monitor en uit menslikheidsoorwegings opkom vir die regverdige behandeling van almal. Selfs nie-christen-groepe se vryheid van godsdiensbeoefening moet vir hulle gewaarborg kan word.

5. Tweedens is daar egter ook die uitdaging wat die bereiking van hierdie groepe bied. Dit is so dat hierdie groepe meermale uit kulturele oorwegings geslote was vir die evangelie. Maar dit is ook so dat daar dikwels in die verlede van hierdie groepe vergeet is of dat hulle op onsensitiewe wyse benader is. As die kerk glo in sy boodskap, kan hierdie mense nie (langer) die geleentheid ontneem word om by Christus uit te kom nie. Die benadering van hierdie groepe sal nie alleen kulturele sensitiwiteit vra nie, maar veral ook ' $n$ besliste onderneming om bekeerlinge met groot hartlikheid te ontvang en tuis te laat voel in die christengemeenskap.

6. Die bediening van die christene uit hierdie groepe vra vir net soveel sorg. In die geval van duisende geskied die bediening sonder enige haakplek en is die mense doodgelukkig om maar in ander tale te 
aanbid, en hulleself tuis te maak in multi-etniese gemeentes. Maar soms is dit tog so dat daar nie genoeg moeite gedoen word om hierdie groepe in te skakel en erkenning te gee nie. Weer eens word hier 'n sensitiwiteit gevra, en wysheid, om aan die verskeidenheid ruimte te bied midde-in die eenheid en gemeenskap van die heiliges.

Dit behoort duidelik te wees dat die aandag aan die minderheidsgroepe vir die lewe van die kerk in Suid-Afrika belangrike implikasies het.

\section{Stedelike groepsgebiede}

1. 'n Aansienlike persentasie van die bevolking van Suid-Afrika woon in aparte woongebiede in die stede van die land. Wat die blankes en Indiërs betref, is dit meer as 90 persent van die bevolking. Dieselfde geld vir nagenoeg 70 persent van die kleurlinge. Die swartes, hoewel nog nie vir 40 persent verstedelik nie, vorm egter reeds die absolute meerderheid van die inwoners van die stedelike woonbuurtes. Dit is veral op die swart scenario dat ons hier die lig laat val.

2. Soos die ander reeds geskilderde prentjies is hierdie een nie mooi nie. Die eerste aanduiding hiervan is die behuisingsituasie. ' $n$ Paar feite in hierdie verband:

* In 1981 was die agterstand in behuising in Soweto alleen 35000 eenhede, wat jaarliks met 4000 vermeerder.

*Die Oos-Rand se amptelike tekort was 24000 , maar so veel as 50000 gesinne het reeds in agterplaaskrotte gewoon.

* Daar moet voor die jaar 2000 meer swart huisvesting opgerig word as wat gebou is sedert Van Riebeeck se tyd.

3. Nie alleen is daar ' $n$ geweldige kwantitatiewe tekort aan huisvesting in die stad nie, maar ook die kwaliteit is ' $n$ knelpunt. Die huise is te klein en daar is geweldige oorbewoning. Die meeste huise voldoen nie aan die behoeftes van die inwoners nie. Afgesien van gesinslede woon daar om verstaanbare redes ook ander familielede of selfs ander loseerders in die meeste huise. Die gevolg van die oorbewoning is ' $n$ algehele gebrek aan privaatheid en lewensruimte, en dikwels 'n ongesonde kamerbesetting.

4. Sommige van die dramatiese stappe wat nodig is om hierdie toestand die hoof te bied, is reeds geneem, maar daar gebeur nog te min om werklik die situasie te verlig. Hier is sekerlik 'n terrein waar die kerk se 
profetiese roeping op die proef gestel word.

5. Die belangrike punt is dat hierdie behuisingsomstandighede grootliks bygedra het tot die endemiese gesinsverval wat in die swart stedelike gemeenskappe ingetree het. Die jeugrevolusie van die afgelope dekade het ook hierin sy grond: die fondament van ' $n$ gesonde samelewing, en die gesag wat vanaf die gesin uitgaan, het verval. Losbandigheid het dure gevolge op alle terreine van die lewe.

6. Die sosiale omstandighede in die swart woonbuurte is dus nie gunstig nie. Daar moet onthou word dat ook die behuisingstekorte grootliks die gevolg was van 'n beleid waarvolgens die swartes in die stad as "tydelik" beskou is. Daar was dus min pogings om werklik gesonde, gebalanseerde gemeenskappe moontlik te maak. Die mate waarin dit wel gebeur het, is slegs in ' $n$ mindere mate te danke aan amptelike pogings.

7. Die politieke druk in die swart woonbuurtes is geweldig. Mense vind dit baie moeilik om onbetrokke te bly. Pro-regering standpunte is nie alleen moeilik as gevolg van die werklike griewe nie, maar selfs gematigdheid word toenemend onder druk geplaas deur gebeure soos die slepende noodtoestand wat hierdie woonbuurtes feitlik beleër gelaat het, sowel as die optrede van drukgroepe.

8. Hiermee is enkele trekke van die situasie geskets waarbinne die kerk en sy gemeentes sy roeping moet uitleef. Struktureel kan gesê word dat die kerk goed gevestig is in die stad. Kerkgang is steeds ' $n$ bekende deel van die "Sunday scene". Die gemeentes het, afgesien van die algemene situasie, geen spesifieke probleme om in die stad te funksioneer nie. Terwyl daar sekerlik altyd groot ruimte vir verbetering is, is hierdie gemeentes, in vergelyking met dié op die platteland, in ' $n$ gunstige posisie.

9. Maar hoedanig is die invloed van die kerk op die stadsbevolking? Hieroor is daar groot rede vir kommer. Dit lyk asof die kerk se invloed in ' $n$ groot mate beperk is tot die private lewe van die stedelinge, en baie min indien enige rol speel in die openbare en beroepslewe van die lidmate. Gesien egter die algemene sosiale stand van sake, lyk dit ook nie asof die kerk werlik ' $n$ houvas op die persoonlike handel en wandel van die lidmate het nie. Hierdie tradisionele werksterrein van die kerk moet in die nuwe situasie van die stad sekerlik meer toegespitste aandag kry.

Maar in die besonder sal die kerk op die een of ander manier meer betrokke moet raak by die openbare en bedryfslewe van die stad. Ander 
organisasies - soos bogrondse en ondergrondse politieke bewegings, die opkomende vakbonde, en sosiale klubs soos die "burial societies" bepaal in ' $n$ groot mate die rigting en moraliteit van die stedelike lewe. Die kerk sal, ter wille van die evangelie, verlore grond moet herwin.

10. Een ander besondere uitdaging vir die kerk lê op die terrein van verhoudinge. In Suid-Afrika is swart-wit verhoudinge ten enemale 'n kernsaak. Die versoeningstaak van die kerk - sowel in die swart as die ander gemeenskappe - sal nie aan ander instansies oorgelaat kan word nie. Ten slotte gaan dit oor die verhoudinge tussen christene! Die swart kerk, oftewel die kerk in die swart woonbuurtes, sal 'n besef van sy roeping moet ontwikkel, ' $\mathrm{n}$ roeping om in hierdie wêreld, deur sy betrokkenheid en deur sy sending, 'n versoenende rol te speel.

\section{Blanke stedelike gemeenskappe}

1. Die relatiewe welvarendheid van die blanke stedelike woonbuurtes versluier die feit dat ook hier 'n groot sendingtaak vir die kerk oorbly. Omdat die woonbuurtes tradisioneel as christelik beskou is, en omdat dit eintlik die plek is waar die kerk in die land gevestig is, is die sendingtaak altyd elders gesoek. Dit hang ook saam met die beeld wat die deursnee christenlidmaat van die sending het, naamlik werk onder (a) nie-blankes wat (b) onderontwikkeld en arm is.

2. In watter mate is die lewenstyl in die blanke woonbuurtes christelik? Sowel vir die gevoelige persoon, as vir die oorgrote meerderheid burgers wat ekonomies gesproke swaarkry, is die spandabelrige en plesiersugtige gewoontes van die deursnee blanke 'n struikelblok. Daar is min blyke van ' $n$ bewustheid van die behoeftes van mense rondom hulle. Selfs die kerke het maar deel geword van die luukse lewenswyse.

3. Die hoë lewenstandaard voed ideologieë wat die nadenke oor enigiets beinvloed. Polities gesproke is die finale argument die veiligheid en behoud van die bevoorregte lewenswyse. Ekonomies gesproke word die kapitalistiese stelsel, wat die voorspoed gebring het, tot uitgangspunt gemaak. Selfsug, en vrees vir verlaging van standaarde, is maar te duidelik die dryfkrag agter beslissings, en slegs in 'n mindere mate die christelike beginsels.

4. Die gemeenskappe word dan ook gekenmerk deur hulle geslotenheid. Om te midde van die breër realiteite so 'n anderse lewenstyl te kan handhaaf, is dit nodig om die geledere te sluit. Selfs die 
kerk neig om, teen sy eintlike aard in, dieselfde geslotenheid te openbaar. Die sending is die enigste deur wat na buite oopgaan, en dan ook (per definisie) slegs na ander gemeenskappe. Die diens van barmhartigheid, die betrokkenheid by armes en verdruktes, is begrens tot diegene in hulle eie gemeenskap.

5. In 'n groot mate sal die kerk se taak in hierdie gemeenskappe dus daarop neerkom om hierdie bysiendheid en na-binne-gekeerdheid van die gemeentes om te keer. Die vensters na die wêreld moet geopen word sodat hierdie gemeentes sake in perspektief kan sien en kan besef dat die krampagtige vashou aan eie voorregte uiteindelik tot ' $n$ verlies van alle geloofwaardigheid kan lei.

Wat die diens van barmhartigheid betref, sal die nood in die groter gemeenskap aan die man gebring moet word. Die sending sal in sy volle omvang uitgeleef moet word. Dit sou nie help om lippediens aan die sending te bewys, maar basies 'n geslote gemeenskap te bly nie.

6. 'n Toetssaak vir die kerk in die blanke woonbuurtes is die inskakeling en die behartiging van die welsyn van die huisbediendes. Hierdie mense is in die verlede raakgesien, maar het alleen binne die ou geslote raamwerk aandag geniet. Dit bly 'n uitdaging van die toekoms.

\section{Nuwe stadsbewoners}

1. Hierdie scenario toon groot ooreenkomste met van die ander reeds genoemdes, maar verdien tog, in die lig van die voortsnellende proses van verstedeliking, ' $n$ aparte behandeling. Die nuwe stadbewoners word onderskei van die stadswaarts-neigende bewoners van die informele nedersettings enersyds, en die reeds gevestigde bewoners van die woonbuurtes andersyds.

2. Vir hierdie mense, soos deels ook by die ander die geval is, kom die verstedelikingsvraagstukke (behuising, lewenstyl, gesinslewe, politieke druk, ens.) en die industrialiseringsaanpassings (eise van die bedryf, die moontlikheid van werkloosheid, die betrokkenheid by vakbonde en informele bedrywe, ens.) gelyktydig op hulle af. Dit is baie moeilik om alles te verwerk. 'n Rustige aanpassing is nie moontlik nie.

3. Die nuwe omstandighede vra ingrypende aanpassings. Al die verhoudings wat saak maak, het verander. Om hulle voete te vind en weer eens ' $n$ vol en sinvolle lewe te hê, het hulle hulp nodig.

4. Dit lê voor die hand dat die kerk se bediening hierin 'n belangrike 
rol kan speel. Praktiese aspekte hiervan sal wees: die opsporing en inskakeling van nuwe intrekkers by die kerk en praktiese hulp in verband met hulle aanpassings. Daar kan gesê word dat die kerk se roeping ten opsigte van hierdie mense hoofsaaklik neerkom op die koinonia-aspek: gemeenskapsvorming is die groot taak.

\section{Stedelike subkulture}

1. Die groot stede van Suid-Afrika het pluralisties geword. Daar kan allerlei subkulture geïdentifiseer word, verskeie waarvan glad nie met die evangelie bereik word nie.

2. Veral in die middestede woon daar verskeie immigrantegroepe wat 'n tipies Europese lewenswyse voer, en in die proses ' $n$ atmosfeer skep wat talle gewone jongmense saamneem. Woonstelgebiede soos Hillbrow in Johannesburg en Sunnyside in Pretoria, om van die hawestede nie te praat nie, vertoon in sommige opsigte ' $n$ tipies boheemse lewenswyse, die sogenaamde "swingers", die dwelmslawe en die saamwoon-brigade. Toenemend word ook die studente-gemeenskappe deur hierdie lewenswyse beïnvloed. Die tipiese voorstedelike kerk bied vir hierdie subkultuur baie min. Die kerk sal sy ratte moet verander om ook hierdie mense met die evangelie te bereik.

3. ' $n$ Ander groep met eie behoeftes is die duisende bejaardes wat in die woonstelle van die middestede woon. Baie van hulle het te kampe met dalende effektiewe inkomstes en ondervind groot probleme. Soos wat die woonstelle verkoop word, moet hulle verhuis na ander beskikbare huisvesting om uiteindelik dikwels haweloos te raak. Die meeste van hierdie mense het langjarige verbintenisse met 'n kerk, en het die gemeenskap van die gelowiges en die liefdevolle betrokkenheid van christene nou meer nodig as ooit. Juis die kerk in die middestad het egter te kampe met groot bestaansprobleme wat dit moeilik maak om by hierdie daadwerklike behoeftes uit te kom.

4. Vir die kerk in die middestad is daar dus 'n omvattende roeping van evangelisasie, diakonaat en gemeenskapsbeoefening in ' $n$ uitdagende omgewing waar die gevaar steeds bestaan dat die kerk oudmodies raak, ' $n$ aspek van die ou lewenswyse wat vir goed agtergelaat is.

\section{Slot}

Die sendingtaak in Suid-Afrika is met ander woorde by verre na nie af- 
gehandel nie. Met die Woord feitlik orals bekend, moet die meer intensiewe fases van sendingwerk egter nou herontdek word en intensiewe aandag geniet. Die "sendingveld" is ook nie meer "daar" nie, maar orals - ook waar dit vroeër nie verwag is nie.

Meer aandag sal gegee moet word aan die missionêre gemeente. Wat is die kerk tog anders as Christus se missionêre liggaam in die wêreld? Mag die kerk - ook die NG Kerk - steeds meer gehoorsaam wees aan Gods bedoelinge. 